\title{
Decolonizing the Academy - Between a Rock and a Hard Place
}

Dr Suhraiya Jivraj (Kent Law School, University of Kent, UK)

\section{Abstract}

I draw on my own experience facilitating a student-led 'decolonizing the curriculum' project within an English university critical law school. I reflect upon how such initiatives - predicated on collaboration between staff and students in particular - can constitute 'liberatory' spaces from which to resist different structural forms of coloniality and racism or racialization within the western academy. I draw on the work of scholars of colour who expose the coloniality and racialization underpinning the current trend within higher education institutions (HEls) equalities initiatives that 'gaze' upon bodies of colour through the phenomenon of the 'BME attainment gap'. This same scholarship also facilitates scholars and students of colour to theorize the possibilities for (re-)existing within the academy by calling for a re-focusing of attention and 'gaze' back onto institutional racism within HEls. The process is rife with pitfalls, navigating continued racialization or erasure on the one hand, to cooptation - in the current increasingly marketized UK HE environment - on the other. Finding oneself in this situation - between a rock and a hard place - is also particularly fraught for academics of colour who are effectively rendered complicit through their wage relation with universities reproducing knowledge systems, that emerged from and continue to be marked by coloniality and racialization. What then is the allure for us to engage in university decolonizing movements? I argue that doing the work of confronting these tensions is an urgent task that must be done alongside finding spaces - albeit cracks and fissures - from which to do crucial antiracist work of 'decolonizing the western academy'. This is not an end-goal in and of 
itself - not least perhaps because of its impossibility - but rather as part of a selfliberatory process facilitating the re-existence of people of colour within the academy.

\section{Keywords}

Decolonizing the University - Anti-racism - Institutional Racism/Whiteness Student-Staff Collaboration - Relationality - Re-existence

\section{Introduction}

What is the allure for academic/activists of colour ${ }^{1}$ - including myself - engaging in decolonizing the academy campaigns within colonial centres such as England? ${ }^{2}$ Many of us, excited to see a re-invigorated, grassroots student-led and initiated movements in the UK have not hesitated to jump on the band-wagon to 'decolonize' our own departments, universities and perhaps even specific fields of research (e.g. Adebisi, 2019; Dar, Dy and Rodriguez, 2018). Yet, what do we view as the social justice gains? What are the specific objectives, both in terms of the process and any potential outcomes beyond the now more widely pursued objective of diversifying reading lists with more scholars of colour (NUS, 2015), including from the global south? Is there a broader goal beyond expanding what is thought of as the 'canon' of knowledge? (Hall and Tandon, 2017; Olufemi et al, 2019; Gopal, 2017).

Whilst students have continued their call to 'decolonize' their curriculum and universities (e.g. SOAS, 2017; Keele, 2018; Cambridge, 2016), It is clear that for institutions themselves, the policy impetus is to address what has been labelled the 'BME attainment gap' (Berry and Loke. 2011; Advance HE, 2017); namely that 'black 
and ethnic minority' students are less likely to obtain a good degree (classified as a first or upper second) than their white peers. The strategies employed to address this attainment disparity have been operationalized under 'Equalities, Diversity \& Inclusion' (EDI) or Student Success frameworks (e.g. Kingston, 2012; UCL, 2019). Some universities have gone down the 'kite mark' route by signing up to the Race Equality Charter (REC). Other higher education institutions (HEIs) are also engaged in developing 'inclusive curriculum' frameworks and other policies highlighting the importance for students of colour to feel a sense of 'belonging' within the institutions in order to raise attainment (SOAS, 2018; UCL, 2019; Kingston, 2012).

Scholars of colour have engaged with these institutional responses in a range of ways including from social justice and anti-racist perspectives. Shilliam (2017), for example, insists on the need to move away from 'deficit' approaches - which posit students as 'the problem' who “...marked by race - resist all efforts to develop them, economically and intellectually" (Tuitt, 2018, 5) and therefore need 'fixing' - through various (remedial) interventions. Others, such as Tate and Bagguley (2017) - along with the contributors to their collection on 'Building the Anti-Racist University'- focus on the need to meaningfully shift the analytical and policy gaze onto forms of institutional racism, which they argue act as barriers to achievement and progress within HEls for both students and staff (See also Joseph-Salisbury 2019).

The official UK definition of institutional racism emerged from the Macpherson report (1999) resulting from a public inquiry into the police's investigation of the murder of black teenager Stephen Lawrence in 1997. The report described it as: 
"The collective failure of an organization to provide an appropriate and professional service to people because of their colour, culture, or ethnic origin. It can be seen or detected in processes, attitudes and behaviour which amount to discrimination through unwitting prejudice, ignorance, thoughtlessness and racist stereotyping which disadvantage minority ethnic people."

The report and the definition have been fervently debated amongst scholars (Philiips 2011). Whilst there is a shared commitment amongst them and policymakers to tackle racial and other disparities in all areas impacting the lives of people of colour, including in education, there is also fervent debate between them on how best to achieve this. I focus on the debate amongst anti-racist scholars who recognize that, as Tate and Bagguley put it, we are "all touched by the machinations of European empire whether as colonized or colonizer" $(2017,289)$. Scholars who start from this underlying position recognize the need to map and understand the different manifestations of the broader framework of coloniality/decoloniality or the 'colonial matrix of power' (CMP) as decolonial studies scholar Walter Mignolo (2018) articulates. For him, "there is no modernity without coloniality" because "coloniality is constitutive, not derivative, of mo-dernity" from the times it "was constituted, managed, and transformed from its historical foundation in the sixteenth century to the present" $(2018,3)$.

In Tate and Bagguley's terms, this idea of the CMP would be described as manifestations of "European whiteness as superior" which in turn points to the "abjection" and "difference of racialized others" (289). In this context whiteness - or, as I discuss in the final section, what Yancy $(2008,2012)$ calls 'whiteliness' - refers 
to "discursive and non-discursive aspects of institutional life" and "a way of performing both one's phenotypic white body and one's subjectivity structured around a specific white racist epistemic orientation." (2008, 48 cited in Tate and Bagguley, 2017, 293; see also Joseph-Salisbury, 2019). What is key to these differing formulations is the acknowledgement of an underpinning "colonial psyche [Fanon 1986] which still exists in the twenty-first century" that "...actively deracinate[s] politics, subjectivities, political economy, and affective relationalities" (289) including within and indeed emanating from the (colonial) traditions of the (English/British) University. As Ferguson (2012) - and others I draw on - argue, the University as an institution produces the state and its actors, not just the other way around. Rather, it both excludes and then includes to fashion them in its own way and for its own purposes. This is happening even as the same universities are reimagining and reconfiguring themselves to be leading equality, diversity and inclusion (EDI) policies which are often largely ineffectual at best or rather reinforce harms in ignoring the link between attainment disparities and institutional racism (Tate and Bagguley, 2017, 290; Ahmed, 2012; Shilliam, 2017).

Whilst the critical race/decolonial studies scholars have sometimes competing views on the potential 'roadmap' for change I explore how we may perhaps view it as a continuum of perspectives. At one end would be those like Andrews (2018) who would only settle for wholesale revolution of the 'colonial university', or Shilliam (2015) who writes about the university as having opened its doors to people of colour yet "the architecture remains the same". Others seek to 'reframe and reform' from within the University (see Pete, 2018) or work towards exploring how to build the anti-racist university (Tate and Bagguley, 2017). I reflect upon the pitfalls and gains 
of facilitating a student-led 'decolonizing the curriculum' situating it within this continuum to explore the potentialities for a student staff anti-racist collaboration in a space carved out from 'between a rock and a hard place'; a liminal space, a crack, a fracture, and even a hub of momentary absences of structural whiteness dominating, albeit looming and sometimes seeping through (Tate and Bagguley, 2017, 294). I discuss the ethical imperatives as well as tensions to continue and be part of this labour and movement from the perspective of being an academic of colour.

I draw on multiple methods of conversation and interaction with students who engaged with and worked on a decolonizing the curriculum project which I ran initially as part of my module on critical approaches to race and religion and law. This included a research-process training programme for the students, reading and discussion groups, reflective conversations in meetings particularly with the focus group leaders, informal chats on buses and trains journeying to events as well as through semi-structured interviews, evaluations of their roles in the project and their research findings published in a Manifesto to the University (Ahmed et al, 2019). As the methodology in the manifesto outlines the project was underpinned by principles of "social justice and co-production inspired by critical race theory [CRT]" (LadsonBillings, 2010). The relationship between critical legal studies and CRT is evident in key works - including Crenshaw's (1999) now well-known articulation of intersectionality thirty years ago. It is in this context that I analyze the data described above, taking a CRT and decolonial scholarship lens together. In doing so I specifically employ a perspective that Patricia Hill-Collins (1986) describes as the "outsider-within" to theorize from my positionality as an academic of colour, who is both complicit in and yet also struggling against, dynamics within an academy 
marked by coloniality. As Bell Hooks reminds us: "Personal testimony, personal experience, is such fertile ground for the production of liberatory feminist theory because it usually forms the base of our theory making" $(1994,70)$. This liberatory feminist - and critical race - intersectional practice undoes the binary drawn between theory and praxis as well as other false dichotomies within which we are required to work in the neo-liberal university, such as: research and teaching and perhaps most importantly, student and staff (Tate, 2019).

The article has three key sections. Firstly, I outline the context within higher education including the material conditions surrounding so-called 'BME' attainment or 'gap gazing'. I also set out the key concepts and theoretical lenses on which I draw - decolonial and anti-racism/critical race studies - and tease out their connections as a way-finder for staff and students of colour and their allies. In the second section I explore the work of scholars of colour in more detail seeking to refocus attention and 'gaze' back onto institutional racism within HEls. I do so through reflexive analysis on decolonizing as process (Bhambra et al, 2018), exploring the tensions that emerge amongst scholars of colour in how to navigate the constant pitfalls of erasure and co-optation in the current increasingly marketized $\mathrm{HE}$ environment. In the final section, I reflect on my own experience facilitating a student-led 'decolonizing the curriculum' project as an essential way to seek out spaces and ways to resist different structural forms of coloniality and racism or racialization within the western academy. I argue that doing so can give rise to the conditions which enable marginalized and racialized peoples to exist within it whilst also recognizing that one is always already co-opted and complicit within it, particularly as waged staff reproducing colonial knowledge systems. In short, 
decolonizing and anti-racism resistance, act as self-liberation towards (re-)existence, both against erasure and/or co-optation - but also with and within it - from between a rock and a hard place.

\section{'BME Attainment' and Gap Gazing.}

Student movements to decolonize the academy have clearly been successful in raising consciousness around the ways in which the Eurocentric academy have impacted those within them whether through the 'white' curriculum and canon or lack of staff of colour, particularly black professors (Okuleye. Y. 2014; NUS, 2015; Chantiluke et al 2019). Perhaps one of the most substantial 'gains' in terms of being one of the most widespread interventions to result from the student movements has been in relation to broadening reading lists. 'Diversity audits', sometimes in conjunction with university libraries - including at my own institution (Kent, 2019) are now more common place putting into process the inclusion of perspectives from (post)colonial peripheries to 'diasporic' ones within the colonial centres, although this has not been uncontested (Shilliam, 2017). Various other developments put forward within the EDI industry include 'inclusive curriculum frameworks' pioneered by Kingston University in a consortium with four other HEls (McDuff and Tatum, 2015). They seek to operationalize a number of methods to tackle the disparities in degree outcomes and students' sense of belonging on campus' as part of improving attainment and employability. Whether this has resulted either nationally or locally in an increased sense of belonging and/or higher degree outcomes for students of colour is certainly not clear (Tate and Bagguley, 2017). There is, however, more acknowledgment that a 'deficit' approach to students - underlying the language of the BME attainment gap - is counter-productive with some emphasis on (critical race) 
approaches to better understand the institutional barriers for students of colour, including whiteness and the impact of its privilege/power within the academy (SOAS, 2018). Whilst this increased awareness is welcome, it is by no means a victory given that focusing on the gap itself deflects attention away from the institutional racism that produces it. Moreover, as we know from recent reports including the joint report from Universities UK (UUK) and National Union of Students (NUS) (2019) and the Office for Students (OFS) (2019) - the UK higher education regulator - as well as from universities themselves, attainment gaps are not really diminishing. Nevertheless, regulatory requirements continue to be developed for universities to tackle their attainment disparities more rigorously in ways that will be (legally) monitored with potential consequences for not meeting targets (OFS, 2019).

The most recent of these interventions, the UUK/NUS 'Closing the Gap' report (2019) highlights five steps that Universities need to take in order to reduce the 'BME attainment gap'. This includes 'having conversations around race and changing culture' and 'develop racially diverse and inclusive environments'. It is the latest highlevel policy report that acknowledges "racial Inequality in the UK" and cites key legislation and research, such as: The Race Relations Act (1965); The McPherson Report (1999); The Equality Act (2010); The Race Disparity Audit (2017/18); The Voluntary Race at Work Charter (2017); reviews by David Lammy MP (2017) and Baroness McGregor-Smith (2017), as well as highlighting racial inequality in higher education. Yet, despite these acknowledgments, the report fails to explicitly name and highlight the problem of institutional racism as a key issue underlying racialized attainment disparity (Thomas and Jivraj, 2019; Thomas 2020). This has the knock-on effect of failing to recommend specific proactive strategies, for example, to address 
the under-representation of 'BAME' people including within leadership positions. This situation is particularly exacerbated, given that the first recommendation from the report is for universities to "provide strong leadership". Yet, it is clear that there is a lack of buy-in at this first crucial point given that only thirteen vice chancellors (out of over 133 universities in England) sat on the working group chaired by Baroness Valerie Amos (Director of University of London School of Oriental and African Studies). It is crucial for university leaders to acknowledge the importance of having more staff of colour - who make up only $0.6 \%$ of the professoriate in the UK (Rollock, 2019) and indeed operationalize strategies to address the lack of staff of colour. In addition, it is clear that (financial) resources including funding for research on race and attainment as well as overseeing clear policies and procedures to address racial and intersectional inequalities and discrimination is vital (Thomas and Jivraj, 2019; Bhopal, 2018; Gabriel and Tate, 2018). It is hard to see how any change is possible without these staff in place and without proper support but is unsurprising given that it is part of the problem of pervasive - but often unseen (Frankenburg, 1993) institutional racism within universities. Instead, the focus of these kinds of reports tend to be on curricular concerns rather than societal and structural factors that perpetuate racial inequalities, including the lack of recognition for the skills and expertise of scholars of colour to research and design interventions and frameworks. Again, this is unsurprising given that even the increase in overt racism on university campuses is so inadequately dealt with (Joseph-Salisbury, 2019) even when reported. However, part of the problem is also a lack of accessible reporting mechanism and channels of communication to ensure accountability and transparency as many student campaigns including the one at my institution (Ahmed et al, 2019) and the Goldsmiths anti-racism occupation (2019) have highlighted. 
What is particularly worrying is the way in which the report co-authored by the NUS seems to highlight the voices of students. It is indeed peppered with student testimonies (including from my own students and institution) and there is little hint of the "sometimes acrimonious relationship between students and Student Unions with some universities even becoming estranged from the NUS" (Thomas and Jivraj, 2019). Moreover, uncensored voices of scholar-activists remain absent, including the numerous student-led campaigning against racism, such as the Goldsmiths antiracism university occupation, one of the longest student occupations in recorded history which took place as a result of the university's failure to address racism on campus. If the findings from the report are to be more representative of 'the student voice', rather than just a "tactical inclusion", and if the report is serious about its recommendations particularly relating to 'having conversations about race and changing culture', meaningful consideration will need to be given to the range of voices and experiences (Thomas and Jivraj, 2019). This includes thinking about those who do not engage with formal communication channels as well as developing an understanding of what the 'hostile environment', including barriers such as the impact of the 'Prevent' (anti-terrorism) duty, are for those students (Hajera et al, 2017). After all, having conversations around race and changing culture cannot work without these students and staff of colour without a full acknowledgement of structural racism and its co-imbrications with whiteness (power and privilege) within HEls both historic and contemporaneous (Bhopal, 2018; Shilliam, 2017).

However, we know of course that this is no easy task. It has proven in fact to be a very difficult and uncomfortable one for all involved as Robin Di'Angelo (2019) writing about 'White Fragility' and Reni Eddo-Lodge (2017) on 'Why I am no longer talking to white people about race' - amongst others - have articulated. Perhaps key to 'having 
conversations about race and changing culture' is also undertaking the task of fully naming the elephant in the room and reflecting more deeply on why it is crucial to shift the gaze back to institutional racism within HEls (Yancy, 2014). After all, as Vaughta and Castagnob (2008) argue, it is time for teachers to understand more fully how their racial attitudes are both informed by and reinforce structural racism within teaching settings. Universities such as Hertfordshire, SOAS and Glasgow are beginning to have these conversations but this is a drop in the ocean of what needs to be done in terms of tackling structural racism. After all, all UK HEls are subject to the neo-liberal forces of National Student Survey (NSS) and other rankings, league tables, charter marks, research/teaching and other 'excellence' frameworks etc. Reputational value from these mechanisms is often critical for funding and marketability and are therefore not conducive to institutional anti-racist work (Dar, Dy and Rodriguez, 2018).

\section{Re-focusing the Gaze on Institutional Racism in HE}

In her review of the 2018 co-edited collection 'Decolonizing the University' (edited by Bhambra, Gebrial and Nisancioglu) Patricia Tuitt sets out what she describes as the "urgent task of decolonizing the BME attainment gap narrative" because of the way it circulates with exclusionary force - through the process of othering - whilst simultaneously espousing the language of inclusion. She states: "By denying the true causes of the BME attainment gap, the presumed intellectual deficit of black and minority ethnic students can be paraded or "exhibited" (Icaza and Vazquez, 2018, 118). The university is a place "...in which some people feel at home and others are alienated..." $(2018,111)$ and where the "...exhibition of diversity functions to reinforce exclusion and discrimination by marking bodies and knowledges as 'the other'" 
(2018, 118). Tuitt takes on the challenge posed by the co-editors to consider decolonization as practice and draws upon the process of decolonization set out by Pete in the chapter entitled 'Meschakanis, a Coyote Narrative: Decolonizing Higher Education'. It is important to note that decolonial studies has been taken up differently in the UK and Europe as compared to North America for example, where indigenous scholars have articulated critiques of the mainstreaming of decolonization which erases decolonial work that originates in the struggle for indigenous sovereignty over their lands under European empire building (Bhambra et al, 2018). However, Pete's process which begins with firstly, seeking to name colonial structures, secondly reframe them and then finally remake and/or reform them $(2018,174$ cited in Tuitt, 2018,3$)$ is a useful approach to critically exploring the potentialities - and pitfalls - of 'decolonizing' work in UK HEls .

For Tuitt, 'naming' as the first step of a decolonizing process highlights the 'BME attainment gap' narrative as yet another instance of how the modern university operates. It simultaneously attempts to "reconcile claims of progress and innovation" with the fact "that the experiences of black and minority ethnic students in the university sector are greatly diminished in comparison to their white counterparts" $(2018,6)$. Tuitt argues that this pattern, similar to other such (historical) narratives, is "deeply engrained in colonial structures" $(2018,5)$. Whilst she and other scholars (Dar, Dy and Rodriguez, 2018) highlight the fact that the narrative centered on 'gaps' is played out in a context of "...accelerated corporatization of the European university landscape..." (Tuitt, 2018, 6) in which institutions are grappling to find their place, there is also insufficient acknowledgment by these same HEls that students of colour are being denied the educational opportunities afforded to their white counterparts (Khan, 2019). I would go further and argue that there is insufficient acknowledgment 
by HEls of their role and responsibility in being a constituent part of institutional racism in perpetuating the BME attainment gap discourse that marks the bodies of students of colour as well as staff.

The governance of these bodies is perpetuated through the 'right interventions' to tackle attainment gaps. For example, both the 'Closing the Gap' report (2019) and the OFS (2018) posit that we just need to know 'what works'. This has resulted in the OFS creating a bank of expertise with funding for 'consortia of universities' attached to it. It is increasingly acknowledged and explained to us (for example at the UUK conference accompanying its report) that part of 'what works' is moving away from a deficit model (Shilliam, 2017) with some universities like Hertfordshire and Brighton, explicitly stating that they have done so. However, even the Vice Chancellor of Hertfordshire University (one of the five universities in the previously mentioned funded 'consortia' to lead initiatives tackling attainment gaps) stated that their BME attainment gap statistics have remained "stubbornly" difficult to shift, despite numerous interventions and measures (McKellar, 2019). These HEl interventions and data illustrate that there is still an underpinning and enduring impact from the belief that "black students arrive at the gates of university with pronounced social and cultural deficits garnered from their familial and community upbringing" (Shilliam, $2018,59)$. It is seemingly apparent that there is an undergirding anxiety and fear that the 'problem' cannot really be solved (Jivraj, 2013). This anxiety is however, constantly covered up or avoided rather than fully analyzed. One wonders why more recognition of the causal factors - amongst $\mathrm{HEI}$ leadership - seems to be still so elusive (Mills, 1997) despite the significant amount of research that has been undertaken (e.g. Vaughta and Castagnob, 2008; Baggueley and Tate, 2018 etc.). The impact of this is significant as avoiding fully acknowledging the 'problem' only 
allows the phenomenon of the 'BME gap' - and gazing upon it - to grow. This in turn perpetuates the policy focus remaining on bodies of colour rather than the problem of institutional and structural racism and whiteness. Drawing from Pete's second step in the decolonization process (2018) and other scholarly work Tuitt, highlights that the 'problem' evidenced by the qualitative data demonstrates the need to be 'reframed' from one of 'BME attainment gaps' to the enduring racialized beliefs and practices underpinning it. $(2018,5)$. Reframing then would move away from perpetuating the marking of bodies of colour in negative statistical forms which students - including those in the 'decolonizing the curriculum project' I led (2019) and those featured in the Closing the Gap report (2019) have repeatedly said they find de-humanizing (Atteeq et al, 2019).

For Tuitt, as others in the Bhambra et al collection (2018), once the 'problem' has been named and reframed - as institutional racism - we can recognize and acknowledge that universities will inevitably fall foul of colonial "techniques and tropes" sitting "at the heart of the 21st Century reinvention of the university" including through the language and process of gap gazing $(2018 ; 179)$. For her "...colonialism is by definition - violent" (Pete in Tuitt, 2018; 179) and perpetuating exclusionary discourse is a colonial narrative that is therefore a form of violence. She believes that these colonial violence's are revealed "...not only in the manner in which lands and resources are originally acquired, but also in how power over these lands and resources is maintained" (Pete in Tuitt, 2018, 179). Territorial acquisition is not only about acquiring land, but also about acquiring the communities either already resident there [students], or "enticed there by the prospects of advancement which invention/regeneration promises" $(2018,3)$. As Tuitt goes on to argue [these communities/students] are then "deemed to be ripe for experimentation and change" 
stating: "...there is no greater violence than that which places on those whose economic futures are laid hostage to various colonial projects the burden of the projects' inevitable weaknesses and failures" (ibid and see also Collins, 2006). What kind of reform then - the final part of Pete's decolonizing process - can 'reframing' the problem of colonial violence - as the prevalence of racial thinking and practice embedded in the structures of the university and the BME attainment gap discourse and paradigm - lead to? Tuitt states:

"In my view, we cannot begin to reform the colonial structures of the university until we confront the fact that... even in the 21st Century, [universities] are deploying surprisingly unreconstructed techniques of colonial imposition and governance...reproducing problematic conceptions of time, space..." (MaldonadoTorres, Vizcaino, Wallace and We, 2018, 66) is well taken." (Tuitt, 2018, 2) (emphasis added).

This brings us to the continuum of perspectives and debates amongst scholars of colour and others on how to respond to the colonial violence of the university. As Tuitt states in relation to the book but also more broadly there is a "split between those who perceive decolonization in the form of a bloodless revolution, and those seemingly inspired by the Fanonian idea that only equivalent force will successfully confront the violence of colonialism." $(2018,6)$.

For example, Andrews sees “...the university...as institutionally and intractably racist..." and as such, not amenable to reform (cited in Tuitt, 2018, 138-139). Tuitt places herself in this split "resolutely on the side of Fanon" following Wynter's critique of relying on "colonial forms of recognition and redistribution" $(2018,80)$. She argues 
that a "bloodless revolution" would need to be dependent upon a "radical casting aside of traditional ways of thinking the violence of colonialism" including concepts such as justice, equality and rights $(2018,6)$. Tuitt goes on to explore what stands in the way of "a bloody confrontation with the colonial university" and speaking out and refusing against issues from the Prevent duty to "unconscious bias training as solutions to institutional inequality" (Last, 2018: 223, cited in Tuitt 2018, 6; see also Tate and Bagguley, 2017). Drawing on the work of the contributors and echoing others she identifies the barriers for ('BAME') academics who often find themselves disproportionately fettered with the labour of 'diversity' work (Ahmed, 2012; Alexander and Arday, 2015). This includes experiencing different forms of fear (Aparna and Kramsch 2018, 103) from dominant and abusive behaviour (Richardson, 2018, 242; Dar and Ibrahim, 2019), exhaustion and impact on mental health (Arday 2015) as well as resulting from the "corporatized research conditions in the neoliberal academy" (Last, 2018, 217).

Given all these factors and that the odds are stacked against staff of colour whether academic, professional services or otherwise - in various ways related to recruitment and progression (Hopkins and Salvestrini, 2018) what are the possibilities, if any, for 'decolonizing' the bastion of empire and coloniality - the English university? What are the potential locations, sites and potentialities on the continuum between "a bloodless revolution and... the Fanonian idea that only equivalent force will successfully confront the violence of colonialism." $(2018,6)$ ? After all we know, as Sandra Kerr (Director of the Race Equality at Work Survey 2018) recently put it "the future is diverse" (UUK Conference Speech, June, 2019). Students of colour already make up a disproportionately large amount of university attendees (Shilliam, 2015). Moreover, it is students of colour initiating decolonizing 
curriculum/universities movements with little or no support and in some cases direct resistance or inertia from the HEls (Tate and Bagguley, 2017). Perhaps students such as those involved in the Goldsmiths Anti-Racist Action (GARA) occupation are motivated to act as "a visceral reaction to the reality that theirs are the bodies on which the '...modern/colonial order' is being subjected to"; as well as being increasingly "aware of the university's '...histories of segregation..." (Icaza and Vazquez 2018, 122 cited in Tuitt, 2018, 5). Yet what is the potential and the possibilities that arise from staff of colour collaborating with students in these movements, given the various barriers of structural institutional racism and whiteness discussed in the first section?

\section{Resistance/Re-existence from Between a Rock and a Hard Place}

"...what is clear is that we are not yet past the need for anti-racist institutional action." (Tate and Bagguley 2017, 289)

There are of course the localized pedagogic and curricula interventions outside of the institutional diversity initiatives, such as Deborah Gabriel's 3D pedagogy framework (2018) - a strategic model of inclusive teaching practice to "decolonize, democratize and diversify" the HE curriculum in higher education (see also Wekker et al 2018). These initiatives are crucial at sustaining bottom up anti-racist work that also relies and thrives on good student-staff interpersonal collaboration and trust; they should not be under-estimated in terms of direct benefit to students. Students of 
colour are here in universities to stay and are therefore becoming consumers of a commodified education with more emphasis on their 'student voices' being heard. So whilst the university is a place "...in which some people feel at home and others are alienated..." (Tuitt 2018, 111) universities, particularly those with 'inclusive curriculum' frameworks, strategies and policies, are increasingly recognizing 'belonging' - and lack of it - as a barrier to attainment (SOAS 2017; UCL 2019; Hensby and Mitton 2017). Yet as discussed earlier many of these initiatives have not addressed structural racism nor even necessarily led to the attainment disparities being eradicated which is unsurprising as they perpetuate racialized logics, or, what Tuitt refers to, as 'colonial violence'. Rather, EDI initiatives often end up co-opting those voices into the marketing of the institutional to recruit yet more students (Dar, Dy and Rodriguez, 2018).

However, are there other ways to explore articulations of 'belonging', perhaps as spaces, albeit small fissures or cracks in the edifice or "architecture" (Shilliam 2015) of the colonial university? Are there interventions that can become momentary points of connection for anti-racist struggle sustained through student-staff interactions and collaboration? I argue there is a crucial relationality - between staff and their students - that characterizes the persistence of scholars who persist in delivering courses where students see themselves, their herstories and their traumas exposed and unravelled (Ahmet, 2019; Tate, 2019; Bhambra et al, 2018). Where they feel a sense of confidence to take academic risks in researching topics that are meaningful to them with less fear that they may be "misunderstood" or "marked down" as a result. Where knowledges are presented and divulged collectively rather than the myth of there being one 'canon' (Ramgotra 2018). Where the classroom is not a place of re-instating hierarchies but facilitating student empowerment and building 
community. As one of the students on the 'decolonizing the curriculum' project I coled put it:

"Coming to class, the reading groups and meetings was not a chore, it was a pleasure, we got to know one another and really be able to exchange ideas and support each other. It was hard and scary at times, the responsibility of running the focus groups and writing up the difficult and sensitive things other students had talked about. But I also loved doing it, grew more confident as we were writing and presenting it at the conference. I didn't think I could publish work let alone co-author a book".

This student has been a key member of the project that grew out of an optional module on critical approaches to race, religion and law. Having experimented with the module content over a number of years I decided it was time to link the course to the wider political context of student movements acting for change in a more embodied way. I designed the module so my students could produce research they could share and disseminate beyond the classroom such as the manifesto and the 'stripping the white walls' podcasts (Ahmed et al, 2019). At the same time, this work also constituted part of their assessment. Students from the module and many others got involved in the project through word of mouth and attending the reading and discussion groups as well as the launch of the project with keynote from $\mathrm{Dr}$ Jason Arday who spoke about 'BAME' students' mental health on World Mental Health day 2018 during Black History Month. What had originally meant to be an inmodule project ended up as a university wide movement with a student committee of seventeen including all undergraduate stages as well as a postgraduate research 
collective with members from various disciplines including STEM, social sciences and the humanities. After having research process training, nine final year undergraduates and one postgraduate student co-led focus groups as informal cafés in locations (including the local mosque) where they felt at ease to talk about various themes. These included racialization and ableism to focusing on specificities of the student experience relating to black men, Muslim women and men as well as running groups open to all. The students were then supported through the writing process by myself to publish their findings in a manifesto of recommendations (2019) across three areas: firstly, on pedagogy and powerful learning experiences, secondly, race, identity and belonging and thirdly, student voice and co-production with academics; being stakeholders within the university. This process was not part of the institutional EDI initiatives, although it was funded by the Deputy Vice Chancellor for Education as part of 'teaching enhancement' and it did bring together staff of colour working on 'student success' in a small team to facilitate the process of researching, writing, disseminating and publishing as well as implementation. Collectively, with the student committee we organized a conference to launch the manifesto. Full to capacity, with no standing room left, the event defied the repeated criticism that students are so hard to engage. The atmosphere was indescribable not least because probably for the first time ever on our campus, people of colour were not just in the audience, but also on - and dominating - the stage, they were the majority not the minority. ${ }^{3}$ Students from the project presented their manifesto and then sat alongside established other scholars of colour from Dr Karen Salt who gave the keynote speech to Drs Deborah Gabriel, Francesca Sobande, Jason Arday, Azeezat Johnson, Remi Jospeh-Salisbury and with spoken word from poet 
Suhaiymah Manzoor-Khan and the student union president Aaron Thomson (DecoloniseUKC, 2019).

Whilst we wait in this hiatus period to see what broader 'implementation' will come about from the student recommendations, if any, it is crucial to take the moment to reflect on the process itself as decolonial praxis, rather than on any outcome. In fact, for reasons of potential or inevitable co-optation perhaps 'outcome' and 'impact' is precisely what we do not want, or at least not entirely. What then has been achieved in this momentary space, between revolution and co-optation - between a rock and a hard place?

In their introduction entitled 'What does it mean to Decolonize', Mignolo and Walsh describe "actionings of decoloniality" as:

"multiple, contextual, and relational; they are not only the purview of peoples who have lived the colonial difference but, more broadly, of all of us who struggle from and within modernity/coloniality's borders and cracks, to build a radically distinct world. Decoloniality... is not a new paradigm or mode of critical thought. It is a way, option, standpoint, analytic, project, practice, and praxis" (Mignolo and Walsh 2018, 4-5, emphasis added).

Drawing from Andean indigenous thinkers Mignolo and Walsh describe relationality, or vincularidad, as "the awareness of the integral relation and interdependence amongst all living organisms (in which humans are only a part) with territory or land and the cosmos" in the search for planetary balance and harmony $(2018,1)$. This is 
crucial in the decolonial framework particularly for those who are aiming to disrupt universalizing discourses characterized by notions of singular authority as demonstrated in academic thought within the idea of a canon. Instead, they seek to encourage and create "pluriversal and interversal" paths where many knowledges can be accessed. This trajectory would not do away with Western European originated thought but place it alongside others (as part of the pluriversal) and allow it to be abandoned, or "not accepting" it if desired, by those seeking to unsettle "modernity's naturalized fictions and imperatives" as the only way $(2018,3)$. This form of "not accepting" is posited not only as resistance but also as re-existence; understood as "the redefining and re-signifying of life in conditions of dignity" (Achinte, 2008, 85-86 cited in Mignolo and Walsh, 2018, 3).

For me, it is clear that relationality/vincularidad between our small team of staff and the students underpinned and enabled the 'decolonizing the curriculum' project. This in turn facilitated the students to become empowered to do the work that they did. To write alternative reading lists missing from our libraries; to demand Caribbean authors be part of core modules; to call out overt racism and question the cultural biases of mental health and wellbeing support providers; or expose the colonial atrocities of seeming heroes venerated in the naming of college buildings after them. We facilitated them through class time, extra sessions we co-organized to come together to read, discuss and be in conversation with decolonial studies academics such as during a masterclass with Professor Gurminder Bhambra or brainstorm craftivism with decolonize Queen Mary University of London students or strategize how to train their teachers with the Building the Anti-Racist Classroom Collective. The importance of this 'community building' and self-liberation is clear from their 
motivation to continue the work, document it further through a co-authored book (2020) to inspire and work with other students including those who will continue their specific university trajectories.

In the face of both increasing overt instances ('KKK'/neo-nazi graffiti) and everyday racism, or what Joseph-Salisbury (2019) refers to as micro-aggressions when "black bodies" in particular are often perceived to be "out of place in HE", these moments of connection - vincularidad - are key for surviving the pain of that racism. To be able to name it, speak it is a way of "not accepting it" particularly when most of the time institutionalized whiteness is seemingly invisible, unnoticeable or "unseen" (Frankenburg, 1993) because it is embedded within modernity/coloniality or CMP as Mignolo and Walsh describe it $(2018,4)$. In such conditions of institutional whiteness and racism resistance and (re-)existence become interdependent (see also Emejulu and Sobande, 2018; and Johnson and Joseph-Salisbury, 2018). This is clear from our 'decolonizing the curriculum' project as well as others such as the participatory research project, Race in the Academy' run by Akile Ahmet (2019) with postgraduate students of colour at the London School of Economics. The process of students and staff working together to catalogue the experiences of exclusion in their university also became a way to create belonging amongst students and crucially with and because of the staff involved. Similarly, at the University of Arts London (UAL) Student Union and Teaching \& Learning Exchange have co-produced a zine on decolonising the arts curriculum which is part of ongoing work to address the attainment gaps at UAL and the call to widen the curriculum (ASU, 2018). Such opening up of cracks and fissures, "venues and paths", which may open up new decolonial horizons are crucial for understanding how students and staff of colour 
can together 'undo, disobey and delink' from institutional whiteness as part of a colonial matrix of power, albeit only moments at a time $(2018,3)$. It allows for the "constructing of paths and praxis toward an otherwise of thinking, sensing, believing, doing and living" (2018:4) that is both resistance and (re-)existence simultaneously. At the same time that the university was celebrating a cultural diversity festival, the decolonizing the curriculum project students felt that the institution did not sufficiently respond to or tackle their fears about racism on campus: from neo-nazi swastika symbols to 'KKK' graffiti sprawled on university walls, and inviting speakers known for their Islamophobic views (Javierre, 2018). Of course, HEls are constrained by liberal frameworks of freedom of speech and the requirement to balance competing views, but it is important to note how often these decisions are made, in whose favour, and to identify the leaders in power making them. When is it better not to respond publicly to overt racism as described above in order not to 'oxygenate it' and when is it necessary to make some a stand that goes beyond gestures that are experienced as tokenistic? With some sustained reflection, one might not need the institution to run 'race and belonging focus groups' with students to figure that one out. Instead, the institution may instead shift its gaze to its own 'BAME' staff recruitment, retention, and progressions gaps as well as meaningfully listening to and engaging with a range of students (not just members of students' unions) through projects such as the ones discussed here. They need to think seriously about how to respond to student voices echoing the sentiment that they did not want to participate in focus groups:

"... as they felt it was unlikely that change would come about in response to the Project. Some even feared being under some kind of "surveillance" from 
the university even though they were assured that their responses would be completely anonymized" $(2019,4)$.

Tackling racism - in all its forms - is key to belonging on campus and attainment, and even within liberal business terms, key to success (Baroness McGregor-Smith 2018). Twenty years after the McPherson report expressly pointed to institutional racism in the Metropolitan Police Force, it is high time for the message to get through in other institutional settings like HE. Nevertheless, in the absence of 'conversations about race and cultural change' which the UUK/NUS report calls for, students and staff of colour resist, exist and re-exist by coalescing around the need to focus those conversations on institutional whiteness. They do so through their collaborative research and interventions whether to decolonize the curriculum and assessment, diversify the library or student wellbeing services, or call out overt racism and create community and principled spaces for and with each other (2019). These practices of "resurgent and insurgent action and thought, including in spheres of knowledge...interrupts and cracks the modern/colonial/heteropatriarchal matrices of power, and advances other ways of being, thinking, knowing, theorizing, analyzing, feeling, acting and living for us all..." (Mignolo and Walsh 2018, 10). They have not yet made headway into what Mills posits as the 'Racial Contract' (1997). This is a situation of white privilege created through "governmental process of subjectification motivated by self-interest" in which white people, Europeans and their descendants derive "personal benefit, and entitlement to undisputed privilege" (1997, 40 cited in Tate and Bagguley 2017, 293). This privilege sits embedded in a world that is created "in their cultural image" with: 
"political states differentially favouring their interests, an economy structured around the racial exploitation of others, and a moral psychology (not just in whites sometimes in non-whites also) skewed consciously and unconsciously toward privileging them, taking the status quo of differential racial entitlement as normatively legitimate, and not to be investigated further." (Tate and Bagguley 2017, 293)

In Mignolo and Walsh's terms, this privilege or racial contract would emanate from and be part of the colonial matrix of power in which institutional whiteness is key to the "root of the problem of continuing racial inequalities in universities" (Tate and Bagguley 2017, 293). As Tate and Bagguley argue the "liberal-inclusive approach based on a commitment to diversity" does not acknowledge the pervasiveness of the racial contract "assured by the intensity of the affective attachment to privilege from those who benefit from it". In fact, because of its affective nature, critiques of the racial contract often fall on 'deaf ears' and racism is "silenced" by 'epistemologies of ignorance'; or rather "unknowing" - sometimes 'unconscious' - but also thereby "deniable" (Mills 1997, 18-19 cited in Tate and Bagguley 2017, 293-5). However, like Mignolo and Walsh, Tate and Bagguley also view a decolonial horizon drawing on the work of Caribbean scholar Glissant (1997) who focuses on "epistemological, societal, and self-liberation" (emphasis added). As with the interdependent notion of resistance and (re-)existence I posited above, self-liberation is a key factor in projects within HEls such as decolonizing the curriculum or 'why is my curriculum white?' Of course, there are various ways to work towards re-existence or selfliberation but the common thread underpinning all these movements and antiracist/decolonial theorizing intertwined with them is that they depend upon being "an 
ongoing relational process" where the "university is a contact zone" even in spite of the imperial legacies $(2017,296)$. On the continuum of scholars of colour that I have explored in this article, I draw power and inspiration from all the work, but sit firmly in the camp of persistence and hope even in an era of increasing marketization; which as Tate and Bagguely remind us, may paradoxically be a catalyst for developing more non-Eurocentric curricula (297). Our next steps then must be resistance as reexistence and self-liberation in ways that are momentary but "continuously reiterated and re-inscribed as racism morphs because white privilege will continue to be maintained in the face of future decolonial assault" (298).

\section{Concluding Remarks}

Existing in the western academy for the majority of marginalized people of colour is always already a struggle which therefore necessitates resistance of various kinds; including having to do 'diversity work' in order to 'make liveable' one's own and other staff and students' difficult material conditions. Whilst this process is undoubtedly painful and at the same time decolonizing movements are increasingly open wide to multiple forms of capitalistic co-optation by the HEls' and the EDI industry, I have sought to explore the potential for self-liberation within certain university decolonizing movements. In doing so I have drawn on critical race and decolonial studies scholarship and drawn from my own experience of being part of a student-staff collaboration to 'decolonize the curriculum'. I have argued that relationality between staff and students - what Mignolo and Walsh (2018) refer to as vincularidad - is a crucial connection necessary to sustaining oneself. To use the language of universities it does create a 'sense of belonging' or what my students would refer to as a community hub. This may occur on university campuses but it is not part of 
university EDI structures because it has been self-created and inspired by particular principles, whether social justice and/or critical race. Anti-racism and decolonization become reflexive practices and process for self-liberation in community with others that enables our re-existence.

\section{Acknowledgements}

A sincere thanks to my anonymous referees as well as Professor Donatella Alessandrini, Dr. Silvia Posocco and Dr. Emily Haslam for extremely helpful comments enabling me to deepen and sharpen my analysis and arguments. This work would not have been possible without the @DecoloniseUKC project students. I would like to thank them for their work on the Kent Law School 'Decolonizing the Curriculum' project and for collaborating with and trusting in me and my team - Dave Thomas, Sheree Palmer, Ahmed Memon and Dr. Barbara Adewumi - so wholeheartedly. It has been a privilege. Thanks also to Philemon Omede for his invaluable research assistance and to my Head of School Professor Toni Williams for supporting this work in challenging times and providing spaces not often available elsewhere in the academy. All errors are my own. 


\section{References}

Adebisi, F. 2019. Decolonisation and the law school.

http://www.bristol.ac.uk/law/news/2019/decolonisation-and-the-law-school.html;

Advance HE, Equality Challenge Unit. 2015. Statistical Report. https://www.ecu.ac.uk/publications/equality-higher-education-statistical-report-2015/.

Advance HE, Equality Challenge Unit. 2005-2019. Equality Charters. https://www.ecu.ac.uk/equality-charters/athena-swan/ and https://www.ecu.ac.uk/equality-charters/race-equality-charter/

Advance HE. 2017. Degree Attainment Gaps. https://www.advancehe.ac.uk/guidance/equality-diversity-and-inclusion/student-recruitment-retentionand-attainment/degree-attainment-gaps

Atteeq, A. Thomas-Asante, M. and Darko, A. 2019. "Student Impact Panel" at the BAME attainment Gap: Learning from Student Experience Conference. https://www.universitiesuk.ac.uk/events/Pages/BAME-attainment-gap.aspx

Memon, A and Olugboyega, J. 2018. "Stripping the White Walls Podcasts." https://decoloniseukc.org/category/stripping-the-white-walls/

Ahmed, W. Kader, H. Khan, A. Memon, A. Olugboyega, J. Otobo-Martins, E.A. Orie, M. Sargeant, J. Shoko, L. with Jivraj S. \& Thomas, D. 2019. Decolonizing the Curriculum Project Manifesto: Through the Kaleidoscope. https://decoloniseukc.files.wordpress.com $/ 2019 / 0^{3} /$ decolonising-the-curriculum$\underline{\text { manifesto-final-2.pdf }}$ 
Ahmed, S. 2012. On Being Included: Racism and Diversity in Institutional Life. Durham: Duke University Press.

Ahmet, A. 2019. "Race in the Academy" Area. (forthcoming).

https://info.Ise.ac.uk/staff/education/Assets/Documents/Inclusive-EducationAction-Plan-2019/Final-Exec-Summary-Race-in-the-Academy-10-April-2017.pdf

Alexander, C., and J. Arday. 2015. "Introduction: Race and Higher Education." In Aiming Higher Race: Inequality and Diversity in the Academy, edited by C. Alexander and J. Arday, 4-5. Runnymede Perspectives. London: Runnymede Trust. https://www.runnymedetrust.org/uploads/Aiming\%20Higher.pdf

Amos, V. 2019. "Black, Asian and Minority Ethnic Student Attainment at UK Universities: \#Closingthegap," no. May. https://www.universitiesuk.ac.uk/policyand-analysis/reports/Documents/2019/bame-student-attainment-uk-universitiesclosing-the-gap.pdf.

Andrews, K. 2015. "The Black Studies Movement in Britain: Addressing the Crisis in British Academia And." In Aiming Higher: Race, Inequality and Diversity in the Academy, edited by C. Alexander and J. Arday, 30-31. Runnymede Trust.

Andrews, K. 2016. "The Psychosis of Whiteness: The Celluloid Hallucinations of Amazing Grace and Belle." Journal of Black Studies 47 (5): 435-53.

Andrews, K. 2018. "The Challenge for Black Studies in the Neoliberal University" in Decolonizing the University edited by G.K. Bhambra., Gebrial, D., and Nişancıoğlu, N. Pluto Press. 
Aparna, K. and Kramsch, O. 2018. "Asylum University: Re-situating KnowledgeExchange Along Cross-Border Positionalities" in Decolonizing the University edited by G.K. Bhambra., Gebrial, D., and Nişancıoğlu, N. Pluto Press.

Arday, J. 2018. "Understanding Racism within the Academy: The Persistence of Racism within Higher Education." In the Fire Now, edited by A. Johnson, R Joseph-Salisbury, and B Kamunge, 26-37. Zed Books.

Arts Student Union (ASU) and University of the Arts London Teaching \& Learning Exchange. 2018. Decolonising the Arts Curriculum. https://www.artssu.com/campaigns/liberate

Basu, L. 2019. Decolonising Economics. https://www.opendemocracy.net/en/oureconomy/decolonising-economy/

BBC Online. 12 April 2019. "Debating society suspended after 'racism' investigation." https://www.bbc.co.uk/news/uk-england-kent-47899264

BBC Online. 22 March 2019. "University of Kent free speech society racism allegations investigated." https://www.bbc.co.uk/news/uk-england-kent47899264

Berry, J, and G Loke. 2011. "Improving the Degree Attainment of Black and Minority Ethnic Students: Investigating Practice." Equality Challenge Unit and The Higher Education Academy Research Report, 83. http://www.ecu.ac.uk/wpcontent/uploads/external/improving-degree-attainment-bme.pdf. 
Bhambra. G.K., Gebrial, D., and Nişancıoğlu, N. "Introduction: Decolonizing the University?" in Decolonizing the University edited by G.K. Bhambra., Gebrial, D., and Nişancıoğlu, N. Pluto Press.

Bhopal, K. 2018. White Privilege: The Myth of a Post-Racial Society. Bristol University Press.

Cambridge University Graduate Students. 2016-2017. Decolonising the curriculum in theory and practice. http://www.crassh.cam.ac.uk/programmes/decolonising-thecurriculum-in-theory-and-practice

Chantiluke, R. Kwoba, B. Nkopo, A. Asheeke, Tovio, ed. 2019. Rhodes Must Fall: The Struggle to Decolonise the Racist Heart of Empire. Zed Books.

Collins, P. H. 1986. "Learning from the Outsider Within: The Sociological Significance of Black Feminist Thought." Social Problems 33 (6): S14-32.

Collins, P. H. 2006. "New Commodities, New Consumers: Selling Blackness in a Global Marketplace." Ethnicities 6: 3, 297-317

Crenshaw, K. 1993. "Mapping the Margins: Intersectionality, Identity Politics, and Violence Against Women of Color." Stanford Law Review. 43 (6) 1241-99

Dar, S and Ibrahim, Y. 2019. "The Blackened Body and White Governmentality: Managing the UK Academy and the Production of Shame". Gender Work Organization. 1-14 
Dar, S. Dy, A. and Rodriguez, J. 2018. Is Decolonizing the New Black. https://www.leftofbrown.com/single-post/2018/07/12/ls-decolonising-the-newblack

DecoloniseUKC Conference Playlist. 2019.

https://research.kent.ac.uk/sergi/kaleidoscope-network-decolonising-the$\underline{\text { university/ }}$

DecoloniseUoK Collective. 2020 (forthcoming). Towards Decolonising the University:

A Kaleidoscope for Empowered Action. CounterPress.

DiAngelo, Robin J. 2019. White Fragility: Why It's so Hard for White People to Talk about Racism. Penguin.

Eddo-Lodge, R. 2017. Why l'm No Longer Talking to White People about Race. Bloomsbury Publishing.

Emejulu, A. and F. Sobande. 2019. To Exist is to Resist. Black Feminism in Europe. Pluto Press.

Frankenburg, R. 1993. White Women, Race Matters: The Social Construction of Whiteness. University of Minnesota Press.

Gabriel, D. 2018. "Pedagogies of Social Justice and Cultural Democracy in Media Higher Education". Media Education Research Journal. 8(1)34. https://deborahgabriel.com/tag/3d-pedagogy-framework/

Gabriel, D. and Tate, S.A. 2018. The Ivory Tower: Narratives of Women of Colour Surviving and Thriving in British Academia. Trentham Books. 
Ghani, H. Zamzam I. Bouattia, M. Hajera, B. Afzal, S. and Mir. S. 2017. "Preventing Prevent NUS Black Students' Officer." National Union of Students. https://www.nusconnect.org.uk/resources/preventing-prevent-handbook.

Gillborn, D. 2007. "Education Policy as an Act of White Supremacy: Whiteness, Critical Race Theory and Education Reform." Journal of Education Policy. 485505.

Goldsmiths Anti-Racist Action. 2019. Occupation Manifesto. https://www.facebook.com/goldsmithsanti/

Gopal, P. 2017. "Yes, We Must Decolonise: Our Teaching Has to Go Beyond Elite White Men." in The Guardian.

https://www.theguardian.com/commentisfree/2017/oct/27/decolonise-elite-whitemen-decolonising-cambridge-university-english-curriculum-literature

Guardian, The. (Various contributors). 2017. "Open the doors and let these books inwhat would a truly diverse reading list look like?" https://www.theguardian.com/books/2017/nov/11/black-and-minority-ethnic-booksauthors-on-decolonising-the-canon-university-english-literature-syllabus

Hall, B L., and R Tandon. 2017. "Decolonization of Knowledge, Epistemicide, Participatory Research and Higher Education." Research for All 1 (1): 6-19.

Holmwood, J. 2018. "Race and the Neoliberal University: Lessons from the Public University" in Decolonizing the University edited by G.K. Bhambra., Gebrial, D., and Nişancıoğlu, N. Pluto Press. 
Hensby, A, and L Mitton. 2017. "Student Success (EDI) Project Phase I: Report 2 Theory and Research on Race and Attainment in UK Higher Education." University of Kent.

Hopkins, L, and V Salvestrini. 2018. Caught at the Crossroads? An Intersectional Approach to Gender and Ethnicity Pay Gaps in Higher Education.

Javierre, A. 2018. "Racist graffiti spotted on campus". Inquire.

https://www.inquiremedia.co.uk/single-post/2018/11/09/Racist-graffiti-spotted-oncampus

Jivraj, S. 2019. "Why are Students Having Uncomfortable Conversations About Race?" Times Higher Education.

https://www.timeshighereducation.com/author/suhraiya-jivraj

Jivraj, S. 2013. The Religion of Law: Race, Citizenship and Children's Belonging. Palgrave Macmillan.

Johnson, A., and R Joseph-Salisbury. 2018. "Are You Supposed to Be in Here?' Racial Microaggressions and Knowledge Production in Higher Education." In Dismantling Race in Higher Education, edited by J, Arday and Mirza, H. 143-60.

Joseph-Salisbury, R. 2019. "Institutionalised Whiteness, Racial Micro-aggressions and Black Bodies out of Place in Higher Education." Whiteness and Education, May, 1-17. 
Keele University Students, 2018. Decolonising the Curriculum Manifesto.

https://www.keele.ac.uk/raceequalitycharter/raceequalitycharter/keeledecolonisi ngthecurriculumnetwork/keelemanifestofordecolonisingthecurriculum/

Kent, University of. 2017. Valuing Everyone: Equality, Diversity and Inclusivity (EDI) Report 2017-18. https://www.kent.ac.uk/hrequalityanddiversity/local/edi\%20report\%202018/edireport2018.pdf

Kent, University of. 2019. "Award Winning Work on Diversifying Reading Lists" https://blogs.kent.ac.uk/staff-student-news/2019/05/16/award-winning-work-ondiversifying-reading-lists/

Khan, O. 2019. Ethnic Minority Pupils Get Worse Degrees and Jobs Even if They Have Better A-Levels.

https://www.newstatesman.com/politics/education/2019/02/ethnic-minoritypupils-get-worse-degrees-and-jobs-even-if-they-have

Kingston University. 2012. "One Kingston: Our Strategy for Equality, Diversity and Inclusion." http://cdn.kingston.ac.uk/documents/aboutkingstonuniversity/equalitydiversity-and-inclusion/documents/2016-2020_EDI strategy.pdf.

Ladson-Billings, G. 2010. "International Journal of Qualitative Studies in Education Just What Is Critical Race Theory and What's It Doing in a Nice Field like Education?" International Journal of Qualitative Studies in Education 11 (1): 7 24.

Ladson-Billings, G, and W F. Tate. 2018. "Toward a Critical Race Theory of Education." Critical Race Theory in Education, no. January 1995: 10-31. 
Last, A. 2018. "Internationalisation and Interdisciplinarity: Sharing across Boundaries? in Decolonizing the University" edited by G.K. Bhambra., Gebrial, D., and Nişancıoğlu, N. Pluto Press.

Law, I. 2017. "Building the Anti-Racist University, Action and New Agendas." Race Ethnicity and Education 20 (3): 332-43.

Macpherson, C. 1999. The Inquiry into the Matters Arising from the Death of Stephen Lawrence.

https://assets.publishing.service.gov.uk/government/uploads/system/uploads/att achment_data/file/277111/4262.pdf

MacSwan, A. 2019. "Katie Hopkins to address University of Kent students in Canterbury at charity event." in KentOnline.

https://www.kentonline.co.uk/canterbury/news/columnist-hopkins-invited-to-talkat-university-event-199728/

McGregor-Smith. 2018. "Race at Work: Review One Year On." Race Disparity Unit. https://www.gov.uk/government/publications/race-at-work-2018-mcgregor-smithreview-one-year-on.

Mcduff, N, and J Tatam. 2015. "Tackling the BME Attainment Gap - the Policy and Research Context, Kingston University, UK," no. 0316.

McKellar, Q. 2019. “The Role of Leadership” at the BAME attainment Gap: Learning from Student Experience Conference.

https://www.universitiesuk.ac.uk/events/Pages/BAME-attainment-gap.aspx 
Meschachakanis, P.S. 2018. "A Coyote Narrative: Decolonizing Higher Education" in Decolonizing the University edited by G.K. Bhambra., Gebrial, D., and Nişancıoğlu, N. Pluto Press.

Mignolo, W, and C Walsh. 2018. "On Decoloniality. Concepts, Analytics, Praxis." In on Decoloniality, Duke University Press.

Ministry of Justice. 2017 "The Lammy Review: An Independent Review into the Treatment of, and Outcomes for, Black, Asian and Minority Ethnic Individuals in the Criminal Justice System."

Mullen, S, and S Newman. 2018. "Slavery, Abolition and the University of Glasgow Report and Recommendations of the University of Glasgow History of Slavery Steering Committee," https://www.gla.ac.uk/media/media_607547_en.pdf.

National Union of Students, 'Why is My Curriculum White?' 2015. https://www.nus.org.uk/en/news/why-is-my-curriculum-white/

Office for Students. 2018. "Universities Must Eliminate Equality Gaps," https://www.officeforstudents.org.uk/news-blog-and-events/press-andmedia/office-for-students-universities-must-eliminate-equality-gaps/

Office for Students. 2019. "New Approach to Access and Participation". https://www.officeforstudents.org.uk/advice-and-guidance/promoting-equalopportunities/our-new-approach-to-access-and-participation/

Olufemi, L, O Younge, W Sebatindira, S Manzoor-Khan, and P Jun. 2019. A FLY Girl's Guide to University Being a Woman of Colour at Cambridge and Other Institutions of Elitism and Power. Verve Poetry Press. 
Onuora, E, A G Merseyside, C Hunt, G Bhattacharyya, R Woodfield, N Mirza, H Bahra, et al. 2008. "Ethnicity, Gender and Degree Attainment Project." Equality Challenge Unit and The Higher Education Academy, 44.

Okuleye. Y. 2014. "Why isn’t my professor black?” http://www.dtmh.ucl.ac.uk/isntprofessor-black-reflections/

Phillips, C. 2011. "Institutional Racism and Ethnic Inequalities: An Expanded Multilevel Framework." Journal of Social Policy 40(1)173-192

Ramgotra, Manjeet. 2018. "Post-Colonial Republicanism and the Revival of a Paradigm." The Good Society, no. 26(1): 34-54.

Rhodes Must Fall Oxford. 2016. https://rmfoxford.wordpress.com/

Rollock, N. 2019. "Staying Power: The Career Experiences and Strategies of UK Black Female Professors." 1-40.

Ross, F. Tatam, J. Hughes, A. Beacock, O and McDuff. N. 2018. "'The Great Unspoken Shame of UK Higher Education': Addressing Inequalities of Attainment." African Journal of Business Ethics 12 (1): 104-15.

Shilliam, R. 2018. Black/Academia in Decolonizing the University edited by G.K. Bhambra., Gebrial, D., and Nişancıoğlu, N. Pluto Press.

Shilliam, R. 2017. "How Black Deficit Entered the British Academy." https://robbieshilliam.files.wordpress.com/2017/06/how-black-deficit-enteredthe-british-academy.pdf. 
Shilliam, R. 2015. "Black Academia: The Doors Have Been Opened but the Architecture Remains the Same." In Aiming Higher Race: Inequality and Diversity in the Academy, edited by J. Arday and C. Alexander, 32-34. Runnymede Trust. https://www.runnymedetrust.org/uploads/Aiming Higher.pdf

SOAS, 2017. Decolonizing the Curriculum: What's all the fuss about? https://www.soas.ac.uk/blogs/study/decolonising-curriculum-whats-the-fuss/

SOAS, "Decolonizing SOAS Learning and Teaching Toolkit for Programme and Module Convenors." 2018. https://blogs.soas.ac.uk/decolonisingsoas/files/2018/10/Decolonising-SOASLearning-and-Teaching-Toolkit-AB.pdf

Tate, S. A. 2019. Where to from here? - Final thoughts (talk) at Building the AntiRacist Classroom Collective, Organising for Liberation Workshop. Leeds.

Tate, S. A, and D Page. 2018. "Whiteliness and Institutional Racism: Hiding behind (Un)Conscious Bias." Ethics and Education, 13 (1): 141-55.

Tate, S. A, and P Bagguley. 2017. "Building the Anti-Racist University: Next Steps." Race Ethnicity and Education 20 (3): 289-99.

Thomas, D, 2020 (forthcoming). Doing Diversity for Success in Higher Education: Addressing Structural Inequalities in The Academy. Palgrave Macmillan.

Thomas, D and Jivraj S. 2019. From \#Closing the Gap to \#Shifting the Gaze: Tackling Institutional Barriers to Attainment. https://blogs.kent.ac.uk/countercurrents/2019/05/16/from-closingthegap-toshiftingthegaze-tackling-institutional-barriers-to-attainment/ 
Tuitt, P. 2017. "Decolonising Curricula: a Legal Case." https://www. patriciatuitt.com/single-post/2017/12/04/Decolonising-Curricula-aLegalCase

Tuitt, P. 2018. "Modern Colonial Monuments: Review of G K Bhambra, D Gebrial, and K Nisancioglu's Decolonizing the University." www.PatriciaTuitt.com

Turney, L, I Law, and D Phillips. 2002. “Institutional Racism in Higher Education: Building the Anti-Racist University: A Toolkit," 1-114. http://www.sociology.leeds.ac.uk/assets/files/research/cers/the-anti-racismtoolkit.pdf.

University College London (UCL), Equality Diversity and Inclusion Team. 2019. "UCL Advancing Race Equality Toolkit.” https://www.ucl.ac.uk/humanresources/sites/human-resources/files/toolkit_0.pdf

UK Government Cabinet Office. 2017. "Race Disparity Audit Summary Findings from the Ethnicity Facts and Figures Website." https://www.england.nhs.uk/publication/workforce-race-equality-standard-datareporting-december-2017/.

Universities UK \& National Union of Students. 2019. Closing the Gap. https://www.universitiesuk.ac.uk/policy-andanalysis/reports/Documents/2019/bame-student-attainment-uk-universitiesclosing-the-gap.pdf 
Vaughta, S. and Castagnob, A.E. 2008. “I Don't Think I'm a Racist”: Critical Race Theory, Teacher Attitudes, and Structural Racism." Race Ethnicity and Education 11(2):95-113.

Vazquez, R. and Icaza, R. "Diversity or Decolonisation? Researching Diversity at the University of Amsterdam" in Decolonizing the University edited by G.K. Bhambra., Gebrial, D., and Nişancıoğlu, N. Pluto Press.

Wekker, G.; Slootman, M.W.; Icaza, R.; Jansen, H.; Vazquez, R. 2018. “Let's Do Diversity: Report of the University of Amsterdam Diversity Commission."

Yancy, G. 2017. Black Bodies, White Gazes. Rowman and Littlefield.

Yancy, G. 2014. White Self-Criticality Beyond Anti-racism: How Does It Feel to Be a White Problem? Lexington Books.

Zembylas, M. 2018. "Ethics and Education Affect, Race, and White Discomfort in Schooling: Decolonial Strategies for 'Pedagogies of Discomfort." Ethics and Education. 13(1): 86-104.

\section{Endnotes}

${ }^{1}$ I use this term to refer to racially minoritized people not as a fixed category to denote representation of a 'group'. When referring to policy documents the terms BME/BAME may also be used although it is not the author's preferred term as minoritizing is part of racializing particularly when people of colour constitute the global majority rather than an 'ethnic minority'. It also hides differentiations in 
racialized experiences which are not homogenous and conflates structural privilege from which some people of colour will benefit more from than others, e.g. based on their citizenship, socio-economic status, (dis)ability or anti-Muslim racism.

${ }^{2}$ I specifically focus on England rather than Britain or the United Kingdom to denote that it is primarily London and its surrounding 'Oxbridge' centres of knowledge production that form key sites of 'colonial' knowledge production. It is also to acknowledge the difference in approaches to education and knowledge production across the devolved nations that may be viewed in themselves as modern postcolonial sites.

${ }^{3}$ This is particularly shocking given that the University has a high number of 'BME' identifying students: $42.41 \%$ at the Medway campus and $22.93 \%$ at the Canterbury campus as compared to the national population (Kent, 2017). 